\title{
HUBUNGAN PENGUASAAN TEORI DASAR AUTOCAD DAN MOTIVASI BELAJAR DENGAN HASIL BELAJAR GAMBAR KONSTRUKSI BANGUNAN SISWA KELAS XI PROGRAM KEAHLIAN TEKNIK GAMBAR BANGUNAN SMK NEGERI 1 STABAT
}

\author{
Riansyah Putra ${ }^{1}$, Edim Sinuraya ${ }^{2}$ \\ ${ }^{1}$ Alumni Program Studi Pendidikan Teknik Bangunan, Fakultas Teknik UNIMED \\ ${ }^{2}$ Dosen Pengajar Jurusan Pendidikan Teknik Bangunan, Fakultas Teknik UNIMED \\ (edimsinuraya@yahoo.com)
}

\begin{abstract}
ABSTRAK
Penelitian ini bertujuan untuk mengetahui hubungan antara Penguasaan Teori Dasar AutoCAD terhadap hasil belajar Gambar Konstruksi Bangunan, hubungan yang positif dan berarti antara Motivasi Belajar terhadap hasil belajar Gambar Konstruksi Bangunan,dan hubungan yang positif dan berarti antara Penguasaan Teori Dasar AutoCAD dan Motivasi Belajar terhadap hasil belajar Gambar Konstruksi Bangunan pada siswa kelas XI Program Keahlian Teknik Gambar Bangunan SMK Negeri 1 Stabat pada Tahun Ajaran 2014/2015.Hasil uji coba tes Penguasaan Teori Dasar AutoCAD diperoleh 36 butir yang valid dan koefisien reliabilitas $=0,945$. Hasil uji coba soal angket Motivasi Belajar diperoleh 25 butir yang valid, koefisien reliabelitas $=0,855$. Berdasarkan pengujian : 1)terdapat hubungan yang positif dan berarti antara Penguasaan Teori Dasar AutoCAD dengan hasil belajar Gambar Konstruksi Bangunan dengan besar korelasi $r_{X 1 Y}=0,637>r_{\text {tabel }}=0,276$ dan $t_{\text {hitung }}=6,009>t_{\text {tabel }}$ $=1,683$ dan dari korelasi parsial diperoleh $\mathrm{r}_{Y(1,2)}=0,422>\mathrm{r}_{\text {tabel }}=0,349$ dan $t_{\text {hitung }}=3,357>t_{\text {tabel }}=1,683$; 2) Terdapat hubungan yang positif dan berarti antara Motivasi Belajar dengan hasil belajar Gambar Konstruksi Bangunan dengan besar korelasi $r_{X 2 Y}=0,711>r_{\text {tabel }}=0,276$ dan $t_{\text {hitung }}=7,352>t_{\text {tabel }}=1,683$ dan dari korelasi parsial diperoleh $r_{Y(1,2)}=0,562>r_{\text {tabel }}=0,276$ dan $t_{\text {hitung }}=4,900>t_{\text {tabel }}=1,683$. 3) Terdapat hubungan yang positif dan berarti antara Penguasaan Teori Dasar AutoCAD dan Motivasi Belajar dengan hasil belajar Gambar Konstruksi Bangunan dengan besar diperoleh $\operatorname{RY}_{Y(1,2)}=0,848>$ $\mathrm{r}_{\text {tabel }}=0,276$ dan uji keberartian korelasi dengan menggunakan Uji-F diperoleh $F_{\text {hitung }}=66,792>F_{\text {tabel }}$ $=3,178$.
\end{abstract}

Kata kunci: Teori Dasar AutoCAD, Motivasi, Hasil Belajar

\begin{abstract}
This study aims to know the relationship between mastery of Basic Theory of AutoCAD on learning outcomes Image Building Construction, a positive relationship and means between Motivation on learning outcomes Image Building Construction, and a positive relationship and means between Mastery of Basic Theory AutoCAD and Motivation toward learning outcomes Image Construction in class XI student Skills Program Architecture Engineering SMK 1 Stabat on the Academic Year 2014 / 2015.Hasil perform test Mastery Theory Basic AutoCAD obtained 36 valid items and the reliability coefficient $=0.945$. The trial results about learning motivation questionnaire obtained 25 valid items, reliabelitas coefficient $=0.855$. Based on testing: 1) there is a positive and significant correlation between mastery of Basic Theory AutoCAD learning outcomes Image Building with large correlation $r X 1 Y=0.637>$ rtabel $=0.276$ and $t=6.009>t$ table $=1.683$ and partial correlation obtained from $\mathrm{Ry}(1.2)=0.422>$ rtabel $=0.349$ and $t=3,357>t$ table $=1.683 ; 2)$ There is a positive
\end{abstract}




\section{Hubungan Penguasaan Teori Dasar AUTOCAD dan Motivasi Belajar dengan Hasil Belajar Gambar Konstruksi Bangunan Siswa Kelas XI Program Keahlian Teknik Gambar Bangunan SMK Negeri 1 Stabat}

and significant relationship between Motivation to learning outcomes Image Building with large correlation $r X 2 Y=0.711>$ rtabel $=0.276$ and $t=7.352>t$ table $=1.683$ and partial correlation obtained from $R y(1,2)=$ $0.562>$ rtabel $=0.276$ and $t=4,900>t$ table $=1.683$. 3) There is a positive and significant correlation between mastery of AutoCAD Basic Theory and Motivation to learning outcomes with a big Image Building Construction obtained $R Y(1,2)=0.848>$ rtabel $=0.276$ and the significance test of correlation using the Test-F was obtained Fhitung $=66.792>$ Ftable $=3.178$.

Keywords: Basic Theory of AutoCAD,Morivation, Learning Outcomes,

\section{Pendahuluan}

Pendidikan dituntut untuk mampu menyikapi tenaga kerja yang terampil guna memenuhi tuntunan kebutuhan tenaga kerja. Lebih dari itu, berbagai keahlian haruslah dimiliki setiap manusia tersebut untuk hidup dan mengatasi kehidupan yang akan datang. Oleh karena itu pendidikan berperan sangat penting untuk menyediakan sumber daya manusia yang bermutu, berkuantitas serta berkualitas dibidangnya. Melihat kondisi yang dialami pada saat ini, yang menjadi masalah besar adalah rendahnya mutu sumber daya manusia yang tersedia.

Sekolah Menengah Kejuruan sebagai bagian penting dari sistem pendidikan di Indonesia yang memegang peranan penting untuk meningkatkan sumber daya manusia, khususnya dalam mempersiapkan tenaga kerja menengah yang berkualitas. SMK sebagai lembaga yang memiliki bidang keahlian yang berbeda-beda yang disesuaikan dengan lapangan kerja yang ada. Di SMK para siswa dididik dan dilatih dengan keterampilan agar profesional dalam bidang keahliannya masing-masing.

SMK Negeri 1 Stabat dengan program keahlian Teknik Gambar Bangunan memiliki kurikulum yang telah disusun berdasarkan program diklat keteknikan masing-masing. Program diklat keteknikan yang ada di SMK ini dibagi menjadi 3 golongan, antara lain : (1) program diklat normatif, (2) adaptif, dan (3) produktif. Dari ketiga program diklat ini, program diklat produktiflah yang merupakan mata pelajaran keahlian yang berhubungan langsung dengan keterampilan siswa. Salah satu mata pelajaran produktif yang dipelajari siswa kelas XI Program Keahlian Teknik Gambar Bangunan adalah Gambar Konstruksi Bangunan.

Berdasarkan hasil observasi awal dan keterangan dari pihak SMK Negeri 1 Stabat,maka diketahui bahwa pada tahun pelajaran 2011/2012 dengan jumlah siswa 30 orang, yang memperoleh nilai $\leq 69$ sebanyak $10 \%$ (3 orang), nilai 70-79 sebanyak 73.4 (22 orang), nilai 80-89 sebanyak $13.3 \%$ (4 orang), nilai 90-99 sebanyak $3.3 \%$ (1 orang). Pada tahun pelajaran 2012/2013 dengan jumlah siswa 28 orang, yang memperoleh nilai $\leq 69$ sebanyak $3.5 \%$ (1 orang), nilai $70-79$ sebanyak $64.4 \%$ (18 orang), nilai $80-89$ sebanyak $28.6 \%$ (8 orang), nilai $90-99$ sebanyak $3.5 \%$ (1 orang), sedangkan pada tahun pelajaran 2013/2014 dengan jumlah siswa sebanyak 31 orang yang memperoleh nilai $\leq 69$ sebanyak $9.7 \%$ (3 orang), nilai $70-79$ sebanyak $74.2 \%$ (23 orang), nilai 80-89 sebanyak 9.7\% (3 orang), nilai 90-99 sebanyak $6.4 \%$ (2 orang).

Dari data tersebut dapat disimpulkan bahwa hasil belajar Gambar Konstruksi Bangunan masih belum optimal. Masih jelas terlihat kurang mampunya siswa memperoleh hasil belajar yang sesuai dengan tujuan pembelajaran yang direncanakan. Siswa yang mayoritas hanya mampu memperoleh hasil belajar dalam kategori kompeten setiap tahunnya. Hanya sebagian kecil siswa yang mampu meraih hasil belajar yang sangat kompeten.

Tidak tercapainya hasil belajar yang diperoleh siswa sebagaimana yang diharapkan dapat dipengaruhi oleh berbagai hal antara lain pemahaman siswa mengenai bagian-bagian konstruksi bangunan, pengetahuan siswa akan teori ilmu bangunan gedung, penguasaan teori dasar menggambar dengan menggunakan berbagai aplikasi dan pengetahuan mengenai bentuk-bentuk nyata bagian konstruksi bangunan gedung yang sering digunakan dalam kenyataannya.

Begitu pula halnya pada mata pelajaran Gambar Konstruksi Bangunan, diharapkan siswa memiliki Penguasaan Teori Dasar AutoCAD yang baik sehingga pembelajaran nantinya dapat berjalan lancar. Aspek Penguasaan Teori Dasar AutoCAD yang dimiliki siswa tidak terlepas dari 
keberadaan aspek lingkungan sosial yang mendukung siswa seperti guru.Bimbingan guru yang terarah dan disiplin dapat membuat siswa lebih mudah dalam belajar sehingga menjadi sebuah daya dorong positif bagi siswa untuk lebih termotivasi mencapai kompetensi seperti yang diharapkan guru tersebut.

Faktor lain yang dapat mempengaruhi hasil belajar siswa adalah faktor kepribadian yang dimiliki siswa antara lain seperti bakat dasar yang miliki siswa, minat belajar yang tertanam dalam diri siswa, dan motivasi belajar yang dimiliki siswa. Sebagaimana Muhibinsyah (2010) menyatakan bakat merupakan kemampuan individu untuk melakukan tugas tertentu tanpa bergantung pada bantuan pelatihan. Seorang siswa yang berbakat akan lebih mudah menangkap segala informasi yang didapat pada saat kegiata pembelajaran dilakukan. Kemudian aspek lainnya yang dapat mempengaruhi tinggi rendahnya hasil belajar adalah minat belajar yang tertanam dalam diri siswa. Dalam hal ini Muhibinsyah (2010) kembali menyatakan minat dapat diartikan sebagai suatu keinginan yang tinggi terhadap sesuatu. Seorang siswa yang menaruh minat yang besar pada suatu hal pasti akan memusatkan perhatiannya pada materi tersebut yang dapat membuat siswa untuk lebih giat dalam belajar. Kemudian faktor internal lain yang dapat mempengaruhi tinggi rendahnya hasil belajar adalah motivasi belajar yang dimiliki oleh siswa. Sebagaimana Winkel (2005) pernah menyatakan bahwa "motivasi belajar merupakan daya penggerak dalam diri siswa yang menimbulkan kegiatan belajar dan menjamin kelangsungan kegiatan belajar itu, sehingga tujuan yang dikehendaki siswa dapat tercapai dengan baik". Dengan adanya motivasi belajar, seseorang akan merasakan adanya kebutuhan untuk mempelajari sesuatu. Seseorang yang telah termotivasi untuk belajar sesuatu akan berusaha mempelajarinya dengan baik dan tekun.

Memperhatikan akan pentingnya aspek-aspek seperti diatas yang diharapkan dapat dimiliki siswa dalam mengikuti pelajaran Gambar Konstruksi Bangunan, maka penulis ingin melakukan penelitian dengan judul "Hubungan Penguasaan Teori Dasar AutoCAD dan Motivasi Belajar Dengan Hasil Belajar Gambar Konstruksi Bangunan Pada Siswa Kelas XI Program Keahlian Teknik Gambar Bangunan SMK Negeri 1 Stabat Tahun Pelajaran 2014/2015".

\section{Kerangka Teoritis, Kerangka Berpikir, Hipotesis}

\subsection{Hakekat Hasil Belajar Gambar Konstruksi Bangunan}

Hamalik (2002) hasil belajar adalah sebagai terjadinya perubahan tingkah laku pada diri seseorang yang dapat diamati dan diukur bentuk pengetahuan, sikap dan keterampilan.Gambar adalah segala sesuatu yang diwujudkan secara visual dalam bentuk dua dimensi sebagai curahan perasaan atau pikiran (Hamalik, 1986:43). Sedangkan menurut kamus Besar Bahasa Indonesia (2001:329), gambar adalah tiruan barang, binatang, tumbuhan, dan sebagainya.Gambar Konstruksi adalah gambar yang memuat informasi-informasi teknis suatu bangunan dengan lebih mendetail, seperti material yang dipakai, konstruksi sambungan, posisi kolom balok, plumbing (perpipaan), kelistrikan, dsb.Maka dapat disimpulkan gambar konstruksi adalah gambar yang digunakan sebagai alat komunikasi yang memberikan ilustrasi tentang bangunan.Dengan demikian dapat disimpulkan bahwa hasil belajar Gambar Konstruksi Bangunan adalah penilaian perubahan tingkah laku pada diri siswa yang diukur dari produk gambar detail konstruksi bangunan gedung yang digambar siswa dan dinyatakan dalam bentuk angka atau huruf.

\subsection{Hakekat Penguasaan Teori Dasar AutoCAD}

Menurut Eko Hadi Wiyono (2007) penguasaan adalah sesuatu yang menunjukan hasil usaha yang akan dicapai seseorang melalui perbuatan belajar yang diperoleh dalam bentuk tingkah laku. Menurut Eko Hadi Wiyono (2007) teori adalah pendapat yang dikemukakan sebagai keterangan mengenai suatu kejadian. Teori merupakan sarana pokok untuk menyatakan hubungan sistematis.Rio Manullang (2014 : 19), mengemukakan "AutoCAD adalah sebuah perangkat lunak komputer yang handal dalam membuat desain baik 2 dimensi (2D) ataupun 3 dimensi (3D). Program ini dirancang untuk membantu para praktisi dalam bidang teknik sipil, arsitektur, desain interior bagi mahasiswa/siswa STM dalam menyelesaikan tugas dan pekerjaan yang berhubungan dengan perancangan bangunan baik itu membuat gambar rumah, bangunan kantor, apartemen maupun pembangunan jembatan."Berdasarkan uraian diatas, dapat disimpulkan bahwa 


\section{Hubungan Penguasaan Teori Dasar AUTOCAD dan Motivasi Belajar dengan Hasil Belajar Gambar Konstruksi Bangunan Siswa Kelas XI Program Keahlian Teknik Gambar Bangunan SMK Negeri 1 Stabat}

Penguasaan Teori Dasar AutoCAD adalah pemahaman yang telah dikuasai oleh siswa yang hanya berbentuk seperangkat konsep, definisi dan proporsi mengenai perintah dasar menggambar dengan menggunakan AutoCAD dan perintah memodifikasi gambar dalam AutoCAD.

\subsection{Hakekat Motivasi Belajar}

Menurut Syaiful Bahri Djamarah (2011) motivasi adalah suatu pendorong yang mengubah energi dalam diri seseorang ke dalam bentuk aktivitas nyata untuk mencapai tujuan tertentu.Hal ini sejalan sesuai dengan pendapat Mc Donald dalam Syaiful Bahri Djamarah (2011) motivasi adalah perubahan energi dalam diri seseorang yang ditandai dengan munculnya feeling dan di dahului dengan tanggapan terhadap adanya tujuan.Selanjutnya menurut Muhibbin Syah (2010) "pengertian dasar motivasi ialah keadaan internal organisme-baik manusia ataupun hewan yang mendorongnya untuk berbuat sesuatu". Dari pendapat-pendapat di atas dapat disimpulkan bahwa motivasi adalah suatu proses dorongan dasar yang menyebabkan perubahan energi dari dalam diri seseorang yang berhubungan dengan persoalan kejiwaan, perasaan dan emosi untuk menggerakannya bertindak melakukan sesuatu dalam mencapai tujuan, kebutuhan atau keinginan.

Kurangnya Motivasi Belajar akan mengakibatkan rendahnya prestasi belajar yang akan diperoleh siswa. Siswa cenderung kurang termotivasi untuk meraih suatu prestasi belajar yang baik. Meraih prestasi belajar yang maksimal menjadi suatu kebutuhan yang harus dipenuhi oleh siswa dalam belajar. Kebutuhan akan meraih prestasi merupakan dorongan untuk mengungguli dan berusaha untuk sukses dalam belajar. Hal ini sesuai dengan teori motivasi yang dikemukakan Mc Clelland. Dalam teorinya, seseorang yang memiliki tingkat kebutuhan yang tinggi untuk mencapai sesssuatu akan lebih tertarik untuk menemukan cara untuk mendapatkan sebuah prestasi dari sesuatu tersebut.Dengan demikian dari penjelasanpenjelasan di atas dapat disimpulkan bahwa yang dimaksud dengan Motivasi Belajar adalah keseluruhan daya penggerak yang timbul pada diri pribadi siswa yang menimbulkan rasa tanggung jawab belajar, memiliki target prestasi, memiliki keinginan belajar kreatif, mempunyai usaha meraih cita-cita, dan memiliki persiapan dalam belajar.

\subsection{Hubungan antara Penguasaan Teori Dasar AutoCAD dengan Hasil Belajar Gambar Konstruksi Bangunan \\ Penguasaan teori dasar merupakan modal} penting bagi siswa dalam proses belajar, tanpa adanya penguasaan teori dasar yang baik maka kegiatan pembelajaran tidak akan berjalan dengan baik dan akan berdampak pada buruknya hasil belajar yang didapat siswa.Jika siswa telah menguasai teori dasar AutoCAD dengan baik, maka seorang siswa akan lebih percaya diri dan fokus untuk mengikuti pelajaran. Hal ini dikarenakan siswa telah memiliki daya pembangkit dalam dirinya untuk mengembangkan lagi teori dasar yang telah dimilikinya.Kondisi ini sering kali menimbulkan perbedaan tingkat pemahaman yang diperoleh antara siswa satu dengan siswa lainnya. Karena pada kasus ini sering menyebabkan pemahaman materi yang didapat antara siswa yang memiliki Penguasaan Teori Dasar yang baik dan yang kurang baik. Kemungkinan besar yang dapat terjadi hanya beberapa orang siswa saja yang dapat langsung mengaplikasikan materi yang telah diajarkan oleh guru sedangkan siswa yang kurang mengerti akan dasar dari pelajaran ini akan tertinggal dalam hal pemahaman dalam menerima materi ajar yang telah disampaikan oleh guru karena harus kembali mempelajari dasarnya terlebih dahulu. Hal inilah yang dapat mengakibatkan rendahnya hasil pembelajaran yang dapat diperoleh oleh siswa.

\subsection{Hubungan Antara Motivasi Belajar dengan Hasil Belajar Gambar Konstruksi Bangunan \\ Motivasi Belajar ini harusnya dimiliki oleh} seluruh siswa dalam mengikuti proses pembelajaran Gambar Konstruksi Bangunan. Beragamnya aplikasi menggambar yang dapat digunakan untuk menggambar detail konstruksi bangunan gedung menjadi lebih mudah dan praktis serta memiliki tampilan yang menarik seperti AutoCAD, Google Sketchup, 3D Studio Max, dan ArchiCAD seharusnya dapat menjadi daya tarik tersendiri bagi siswa untuk mempelajarinya lebih jauh lagi. Akan tetapi kurangnya motivasi yang diberikan guru sering kali membuat siswa tidak termotivasi untuk mempelajari cara menggambar konstruksi 
bangunan gedung dengan menngunakan perangkat lunak komputer. Harusnya dengan perkembangan IPTEK yang semakin canggih pada zaman ini, dorongan-dorongan moril harus sering diberikan kepada siswa. Seperti dikaitkan pada mata pelajaran Gambar Konstruksi Bangunan ini, jika siswa sering diberikan penjelasan akan diperlukannya penguasaan cara menggambar detail konstruksi bangunan dengan menggunakan perangkat lunak ini dalam dunia pekerjaan nanti. Tentunya siswa akan lebih bersungguh-sungguh dalam mengikuti proses pembelajaran Gambar Konstruksi Bangunan.

\subsection{Hubungan antara Penguasaan Teori Dasar} AutoCAD dan Motivasi Belajar dengan Hasil Belajar Gambar Konstruksi Bangunan

Peningkatan akan pengetahuan dasar AutoCAD yang harus dicapai oleh siswa harus lebih diperhatikan lagi dan benar-benar harus dipastikan kembali bahwa siswa yang akan mengikuti pelajaran Gambar Konstruksi Bangunan sudah terlebih dahulu kompeten dalam memahami teori-teori dasar AutoCAD.Harus ditanamkan dalam diri siswa agar para siswa memiliki motivasi yang sangat tinggi untuk menguasai cara menggambar detail konstruksi bangunan dengan menggunakan perangkat lunak. Motivasi Belajar timbul karena adanya keinginan dalam meraih hasil belajar yang baik. Semakin tinggi motivasi yang dimiliki siswa maka semakin giat pula siswa tersebut dalam melakukan usaha, dan sebaliknya siswa yang tidak termotivasi dalam belajar pada umumnya akan mendapatkan hasil belajar yang kurang baik. Jika siswa telah memiliki Penguasaan Teori Dasar AutoCAD yang baik maka secara otomatis akan timbul dalam diri siswa semangat ataupun motivasi yang akan mendorong siswa untuk mengembangkan lebih jauh lagi teori dasar yang telah dimilikinya.

\subsection{Hipotesis Penelitian}

Hipotesis penelitian yang diajukan berdasarkan deskripsi teoritis, penelitian relevan dan kerangka berpikir di atas adalah sebagai berikut :

a. Terdapat hubungan positif antara Penguasaan Teori Dasar AutoCAD dengan hasil belajar Gambar Konstruksi Bangunan. b. Terdapat hubungan positif antara Motivasi Belajar dengan hasil belajar Gambar Konstruksi Bangunan.

c. Terdapat hubungan positif antara Penguasaan Teori Dasar AutoCAD dan Motivasi Belajar dengan hasil belajar Gambar Konstruksi Bangunan.

\section{Metodologi Penelitian}

Penelitian ini dilakukan tanggal 30 April 2015 dan 4 Mei 2015 pada siswa kelas XI Program Keahlian Teknik Gambar Bangunan di SMK Negeri 1 Stabat Tahun Ajaran 2014/2015.

Populasi dalam penelitian ini adalah seluruh siswa kelas XI Program Keahlian Teknik Gambar Bangunan yang terbagi dua kelas TGB 1 dan TGB 2 di SMK Negeri 1 Stabat Tahun Ajaran 2014/2015 yang berjumlah total 55 orang. Mengingat jumlah populasi sebanyak 55 orang, maka seluruh siswa dijadikan sampel penelitian. Sehingga, cara penarikan sampel data yang dilakukan adalah sampel total.

Metode penelitian adalah cara yang digunakan oleh peneliti dalam mengumpulkan data penelitiannya. Sesuai dengan tujuan penelitian ini, yaitu untuk mengetahui hubungan antara Penguasaan Teori Dasar AutoCAD dan Motivasi Belajar dengan hasil belajar Gambar Konstruksi Bangunan. Maka metode yang digunakan dalam penelitian ini adalah metode deskriptif korelasional.

Adapun definisi operasional variabel penelitian ini adalah :

a. Hasil belajar gambar kontruksi, yaitu suatu penilaian perubahan tingkah laku pada diri siswa yang diukur dari produk gambar detail suatu bagian konstruksi bangunan yang digambar siswa dan dinyatakan dalam bentuk angka atau huruf.

b. Variabel Penguasaan Teori Dasar AutoCAD $\left(\mathrm{X}_{1}\right)$ adalah pemahaman yang telah dikuasai oleh siswa yang hanya berbentuk seperangkat konsep, definisi dan proporsi mengenai perintah dasar menggambar dan perintah memodifikasi gambar dalam AutoCAD.

c. Variabel Motivasi Belajar $\left(\mathrm{X}_{2}\right)$ adalah keseluruhan daya penggerak yang timbul pada diri pribadi siswa yang menimbulkan rasa tanggung jawab belajar, memiliki target prestasi, memiliki keinginan belajar kreatif, mempunyai usaha meraih cita-cita, dan memiliki persiapan dalam belajar. 


\section{Hubungan Penguasaan Teori Dasar AUTOCAD dan Motivasi Belajar dengan Hasil Belajar Gambar Konstruksi Bangunan Siswa Kelas XI Program Keahlian Teknik Gambar Bangunan SMK Negeri 1 Stabat}

\subsection{Hasil Penelitian}

Dalam penelitian ini data yang diambil ada tiga jenis yaitu: Penguasaan Teori Dasar AutoCAD $\left(\mathrm{X}_{1}\right)$ dengan menggunakan instrumen penelitian (tes, multiple choice), Motivasi Belajar $\left(\mathrm{X}_{2}\right)$ dengan menggunakan instrumen penelitian (angket), dan Hasil Belajar Gambar Konstruksi Bangunan ( $\mathrm{Y}$ ) dengan menggunakan instrumen penelitian (tes praktek).

\subsection{Deskripsi Data Penelitian}

Berdasarkan data variabel Penguasaan Teori Dasar AutoCAD $\left(\mathrm{X}_{1}\right)$ yang diperoleh dengan jumlah responden 55 orang siswa, skor tertinggi 34 ; skor terendah 16; dengan mean $(\mathrm{M})=24,475$; dan standart deviation $(\mathrm{SD})=4,345$ dengan rentang $(\mathrm{R})=18$; banyak kelas $(\mathrm{BK})=6$; dan panjang kelas $(\mathrm{P})=3$.

Berdasarkan data variabel Motivasi Belajar $\left(\mathrm{X}_{2}\right)$ yang diperoleh dengan jumlah responden 55 orang siswa, skor tertinggi 93 , skor terendah 61 dengan mean $(\mathrm{M})=76,582$ dan standart deviation $(\mathrm{SD})=7,785$; dengan rentang $(\mathrm{R})=32$ banyak kelas $(B K)=6$ dan panjang kelas $(P)=5$.

\subsection{Identifikasi Tingkat Kecenderungan Variabel Penelitian \\ Diperoleh Mean Ideal (Mi) ubahan} Penguasaan Teori Dasar AutoCAD $\left(\mathrm{X}_{1}\right)$ sebesar 18 dan Standart Deviasi (Sdi) sebesar 6.Diperoleh jumlah responden yang termasuk kategori nilai tinggi sebanyak 17 orang $(30,91 \%)$, kategori cukup sebanyak 37 orang $(67,27 \%)$, kategori kurang sebanyak 1 orang $(1,82 \%)$, dan kategori rendah tidak ada. Dengan demikian Penguasaan Teori Dasar AutoCAD siswa kelas XI Program Keahlian Teknik Gambar Bangunan SMK Negeri 1 Stabat Tahun Ajaran 2014/2015 termasuk kategori cukup.

Diperoleh Mean Ideal (Mi) ubahan Motivasi Belajar $\left(\mathrm{X}_{2}\right)$ sebesar 62,5 dan Standart Deviasi (Sdi) sebesar 12,5. dilihat bahwa jumlah responden yang termasuk kategori nilai tinggi sebanyak 17 orang $(30,91 \%)$, kategori cukup sebanyak 36 orang $(65,45 \%)$, kategori kurang sebanyak 2 orang $(3,64 \%)$, dan kategori rendah tidak ada. Dengan demikian Motivasi Belajar siswa kelas XI Program Keahlian Teknik Gambar Bangunan SMK Negeri 1 Stabat Tahun Ajaran 2014/2015 termasuk kategori cukup.

Diperoleh Mean Ideal (Mi) ubahan Hasil Belajar Gambar Konstruksi Bangunan (Y) sebesar
2 dan Standart Deviasi (Sdi) sebesar 0,667. Dapat dilihat bahwa jumlah responden yang termasuk kategori nilai tinggi sebanyak 23 orang $(41,82 \%)$, kategori cukup sebanyak 32 orang $(58,18 \%)$, kategori kurang dan kategori rendah tidak ada. Dengan demikian Hasil Belajar Gambar Konstruksi Bangunan siswa kelas XI Program Keahlian Teknik Gambar Bangunan SMK Negeri 1 Stabat Tahun Ajaran 2014/2015 termasuk kategori cukup.

\subsection{Uji Persyaratan Analisis}

Tujuan dilakukan uji normalitas adalah untuk mengetahui normal atau tidak normalnya data penelitian tiap variabel penelitian. Pengujian ini dilakukan dengan menggunakan rumus Chi kuadrat. Syarat normal dipenuhi apabila $\quad \chi_{\text {hitung }}<$ Xtabel. Dalam penelitian ini ditetapkan signifikansi 5\%. Normal atau tidak normalnya data ditentukan dengan mengkonsultasikan harga $\chi_{\text {hitung }}$ yang diperoleh dengan taraf $\chi_{\text {tabel }}$ dengan taraf signifikansi 5\%.

Tabel 1. Tabel Uji Persyaratan Analisis

\begin{tabular}{clrc}
\hline No. & \multicolumn{1}{c}{ VariabelPenelitiaan } & Xhitung & Xtabel \\
\hline 1 & Penguasaan Teori Dasar & 1,157 & \\
& AutoCAD $\left(\mathrm{X}_{1}\right)$ & & \\
2 & Motivasi Belajar $\left(\mathrm{X}_{2}\right)$ & 3,755 & 11,070 \\
3 & HasilBelajarGambar & 3,648 & \\
& Konstruksi Bangunan $(\mathrm{Y})$ & & \\
\hline
\end{tabular}

Pada diatas diperoleh bahwa $\chi_{\text {hitung }}<\chi_{\text {tabel }}$ pada taraf signifikansi 5\%. Dengan demikian dapat disimpulkan bahwa data Penguasaan Teori Dasar AutoCAD $\left(\mathrm{X}_{1}\right)$, Motivasi Belajar $\left(\mathrm{X}_{2}\right)$, dan Hasil Belajar Gambar Konstruksi Bangunan (Y) adalah berdistribusi normal.

Berikut ini disajikan ringkasan analisis varians yang menguji kelinearan dan keberartian persamaan regresi Hasil Belajar Gambar Konstruksi Bangunan ( $\mathrm{Y}$ ) atas Penguasaan Teori Dasar AutoCAD $\left(\mathrm{X}_{1}\right)$.Diperoleh persamaan regresi $Y$ atas $X_{1}$, yaitu: $Y=2,31383+0,02817 X_{1}$. $\mathrm{F}_{\text {tabel }}$ dengan $\mathrm{db}$ (16:37) pada taraf signifikansi 5\% adalah 1,925 sedangkan $\mathrm{F}_{\text {hitung }}$ yang diperoleh adalah 0,236. Ternyata $F_{\text {hitung }}<F_{\text {tabel }}(0,236<$ $1,925)$ sehingga persamaan regresi $Y=2,31383+$ $0,02817 \mathrm{X}_{1}$ adalah linear pada taraf signifikansi $5 \%$. Selanjutnya untuk Uji Keberartian dan Persamaan Regresi, $F_{\text {tabel }}$ dengan dk (1:53) pada taraf signifikansi $5 \%$ adalah 4,028 sedangkan $\mathrm{F}_{\text {hitung }}$ yang diperoleh adalah 36,112 . Ternyata 
$F_{\text {hitung }}>F_{\text {tabel }}(36,112>4,028)$ sehingga persamaan regresi tersebut adalah berarti. Dengan demikian dapat disimpulkan bahwa koefisien arah persamaan regresi $\mathrm{Y}$ atas $\mathrm{X}_{1}$ mempunyai hubungan yang linear dan berarti pada taraf signifikansi $5 \%$.

Berikut ini disajikan ringkasan analisis varians yang menguji kelinearan dan keberartian persamaan regresi Hasil Belajar Gambar Konstruksi Bangunan (Y) atas Motivasi Belajar $\left(\mathrm{X}_{2}\right)$.Diperoleh persamaan regresi $\mathrm{Y}$ atas $\mathrm{X}_{2}$, yaitu: $Y=1,66690+0,01755 X_{2}$. Dapat dilihat bahwa $F_{\text {tabel }}$ dengan $\mathrm{db}$ (20:33) pada taraf signifikansi $5 \%$ adalah 1,900 sedangkan $\mathrm{F}_{\text {hitung }}$ yang diperoleh adalah 0,327 . Ternyata $F_{\text {hitung }}<$ $F_{\text {tabel }}(0,327<1,900)$ sehingga persamaan regresi $\mathrm{Y}=1,66690+0,01755 \mathrm{X}_{2}$ adalah linear pada taraf signifikansi 5\%. Selanjutnya untuk Uji Keberartian dan Persamaan Regresi, $\mathrm{F}_{\text {tabel }}$ dengan dk (1:53) pada taraf signifikansi 5\% adalah 4,028

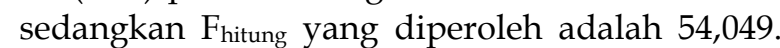
Ternyata $F_{\text {hitung }}>F_{\text {tabel }}(54,049>4,028)$ sehingga persamaan regresi tersebut adalah berarti. Dengan demikian dapat disimpulkan bahwa koefisien arah persamaan regresi $\mathrm{Y}$ atas $\mathrm{X}_{2}$ mempunyai hubungan yang linear dan berarti pada taraf signifikansi $5 \%$.

\section{Hasil Penelitian dan Pembahasan}

4.1 Hubungan antara Penguasaan Teori Dasar AutoCAD dengan Hasil Belajar Gambar Konstruksi Bangunan

Dari perhitungan Korelasi Product Moment diperoleh koefisien korelasi antara $X 1$ dengan $Y$ $=0,637$ sedangkan rtabel dengan $\mathrm{N}=55-2=53$ dan taraf signifikansi $5 \%$ sebesar 0,276 . Dengan demikian harga $\mathrm{rX1Y}>$ rtabel $(0,637>0,276)$. Selanjutnya dilakukan uji keberartian korelasi dengan menggunakan Uji-t diperoleh thitung 6,009 . Harga ttabel untuk $N=55-2=53$ pada taraf signifikansi $5 \%$ adalah 1,683 . Oleh karena thitung $>$ ttabel $(6,009>1,683)$ maka dapat dikatakan bahwa terdapat hubungan positif dan berarti antara Penguasaan Teori Dasar AutoCAD (X1) dengan Hasil Belajar Gambar Konstruksi Bangunan (Y). Selanjutnya untuk melihat hubungan murni tanpa variabel bebas lainnya, dilakukan Uji Korelasi Parsial. Dari perhitungan diperoleh koefisien korelasi parsial antara $X_{1}$ dengan $Y=0,422$ sedangkan $r_{\text {tabel }}$ dengan dengan $\mathrm{N}=55-2=53$ dan taraf signifikansi $5 \%$ adalah 0,276 . Selanjutnya dilakukan uji keberartian korelasi parsial dengan menggunakan Uji-t diperoleh $t_{\text {hitung }}=3,357$. Harga $t_{\text {tabel }}$ untuk $N=55$ $-2=53$ pada taraf signifikansi $5 \%$ adalah 1,683 . Oleh karena $t_{\text {hitung }}>t_{\text {tabel }}(3,357>1,683)$ maka dapat dikatakan terdapat hubungan positif dan berarti antara Penguasaan Teori Dasar AutoCAD dengan Hasil Belajar Gambar Konstruksi Bangunan, dengan variabel Motivasi Belajar dikontrol.

\subsection{Hubungan antara Motivasi Belajar dengan Hasil Belajar Gambar Konstruksi Bangunan \\ Dari perhitungan Korelasi Product} Momentdiperoleh koefisien korelasi antara $\mathrm{X}_{2}$ dengan $\mathrm{Y}=0,711$ sedangkan $r_{\text {tabel }}$ dengan $\mathrm{N}=55$ $-2=53$ dan taraf signifikansi $5 \%$ sebesar 0,276. Dengan demikian harga $r_{X 2 Y}>r_{\text {tabel }}(0,711>0,276)$. Selanjutnya dilakukan uji keberartian korelasi dengan menggunakan Uji-t diperoleh $t_{\text {hitung }}$ 7,352. Harga $t_{\text {tabel }}$ untuk $N=55-2=53$ pada taraf signifikansi $5 \%$ adalah 1,683. Oleh karena $t_{\text {hitung }}>$ $t_{\text {tabel }}(7,352>1,683)$ maka dapat dikatakan bahwa terdapat hubungan positif dan berarti antara Motivasi Belajar $\left(X_{2}\right)$ dengan Hasil Belajar Gambar Konstruksi Bangunan (Y).

Selanjutnya untuk melihat hubungan murni tanpa variabel bebas lainnya, dilakukan Uji Korelasi Parsial. Dari perhitungan pada diperoleh koefisien korelasi parsial antara $X_{2}$ dengan $Y=0,562$ sedangkan $r_{\text {tabel }}$ dengan dengan $\mathrm{N}=55-2=53$ dan taraf signifikansi $5 \%$ adalah 0,276 . Selanjutnya dilakukan uji keberartian korelasi parsial dengan menggunakan Uji-t diperoleh $t_{\text {hitung }}=4,900$. Harga $t_{\text {tabel }}$ untuk $\mathrm{N}=55$ $-2=53$ pada taraf signifikansi $5 \%$ adalah 1,683. Oleh karena $t_{\text {hitung }}>t_{\text {tabel }}(4,900>1,683)$ maka dapat dikatakan terdapat hubungan positif dan berarti antara Motivasi Belajar dengan Hasil Belajar Gambar Konstruksi Bangunan, dengan variabel Penguasaan Teori Dasar AutoCAD dikontrol.

\subsection{Hubungan antara Penguasaan Teori Dasar AutoCAD dan Motivasi Belajar dengan Hasil Belajar Gambar Konstruksi Bangunan \\ Dari perhitungan korelasi ganda diperoleh} koefisien korelasi antara $X_{1}$ dan $X_{2}$ dengan $Y$ yaitu $R_{Y(1,2)}=0,848$ sedangkan $r_{\text {tabel }}$ dengan $\mathrm{N}=$ $55-2=53$ pada taraf signifikansi $5 \%$ sebesar 0,276 . Dengan demikian harga $R_{Y(1,2)}>r_{\text {tabel }}(0,848$ $>0,276)$. Selanjutnya dilakukan uji keberartian korelasi dengan menggunakan Uji-F diperoleh $F_{\text {hitung }}=66,86$. Harga $F_{\text {tabel }}$ untuk $\mathrm{N}=52$ pada 

Konstruksi Bangunan Siswa Kelas XI Program Keahlian Teknik Gambar Bangunan SMK Negeri 1 Stabat

taraf signifikansi $5 \%$ adalah 3,178 . Oleh karena $\mathrm{F}_{\text {hitung }}>\mathrm{F}_{\text {tabel }}(66,86>3,178)$, maka dapat dikatakan bahwa hipotesis penelitian yang diajukan yakni terdapat hubungan yang positif dan berarti antara Penguasaan Teori Dasar AutoCAD dan Motivasi Belajar dengan Hasil Belajar Gambar Konstruksi Bangunan dapat diterima dan teruji kebenarannya.

\section{Kesimpulan, Implikasi, dan Saran}

5.1 Kesimpulan Penelitian

a. Terdapat hubungan yang positif dan berarti antara Penguasaan Teori Dasar AutoCAD dengan Hasil Belaja rGambar Konstruksi Bangunan pada siswa kelas XI Program Keahlian Teknik Gambar Bangunan SMK Negeri 1 StabatTahunAjaran 2014/2015 denganbesarkorelasi 0,637.

b. Terdapat hubungan yang positif dan berarti antara Motivasi Belajar dengan Hasil Belaja rGambar Konstruksi Bangunan pada siswa kelas XI Program Keahlian Teknik Gambar Bangunan SMK Negeri 1 StabatTahunAjaran 2014/2015 denganbesarkorelasi 0,711.

c. Terdapat hubungan yang positif dan berarti antara Penguasaan Teori Dasar AutoCAD dan Motivasi Belajar dengan Hasil Belajar Gambar Konstruksi Bangunan pada siswa kelas XI Program Keahlian Teknik Gambar Bangunan SMK Negeri 1 StabatTahunAjaran 2014/2015 denganbesarkorelasi 0,848.

\subsection{Implikasi Penelitian}

a. Dengan diterimanya hipotesis pertama, maka upaya meningkatkan Hasil Belajar Gambar Konstruksi Bangunan adalah dengan meningkatkan Penguasaan Teori Dasar AutoCAD siswa.

b. Dengan diterimanya hipotesis kedua, maka upaya meningkatkan Hasil Belajar Gambar Konstruksi Bangunan adalah dengan meningkatkan Motivasi Belajar siswa.

c. Dengan diterimanya hipotesis ketiga, maka hal ini menunjukan bahwa Penguasaan Teori Dasar AutoCAD dan Motivasi Belajar yang tinggi mempunyai hubungan yang berarti dalam meningkatkan hasil belajar Gambar Konstruksi Bangunan.

\subsection{Saran Penelitian}

a. Untuk dapat meningkatkan Penguasaan Teori Dasar AutoCAD diharapkan siswa lebih sering dilatih menggunakan toolbar editing dalam menggambar dengan AutoCAD agar siswa lebih paham menggunakan perintah-perintah memodifikasi gambar sesuai dengan ketentuan. Guru diharapkan lebih sering memberi materi latihan menggambar dasar dengan toolbar drawing sampai dengan proses editing gambar dengan AutoCAD. Dengan adanya upaya tersebut, maka Penguasaan Teori Dasar AutoCAD siswa dapat ditingkatkan.

b. Untuk membangkitkan Motivasi Belajar yang ada pada diri siswa Guru harus lebih memperjelas tujuan pembelajaran dan memberi gambaran akan kesuksesan yang dapat diraih siswa. Guru diharapkan dapat menciptakan suasana belajar yang menyenangkan agar siswa menjadi lebih tertarik mengikuti pelajaran dan jauh dari perasaan bosan. Dengan adanya upaya tersebut, Motivasi Belajar dalam Gambar Konstruksi Bangunan dapat ditingkatkan.

c. Untuk meningkatkan Hasil Belajar Gambar Konstruksi Bangunan diharapkan Guru lebih sering memberikan latihan dalam menggambar dengan menggunakan aplikasi komputer seperti AutoCAD atau aplikasi menggambar lainnya, Guru diharapkan sering mengenalkan kepada siswa mengenai informasi terbaru mengenai perkembangan dunia konstruksi saat ini, serta Guru juga diharapkan selalu berusaha memberikan penjelasan mengenai manfaat dari kompetensi yang akan diperoleh siswa sebagai modal meraih kesuksesan di masa depan setelah memperoleh kelulusan nanti.

d. Untuk lebih memperluas hasil penelitian ini diharapkan perlu diadakannya penelitian lebih lanjut tentang hubungan Motivasi Belajar dan Penguasaan Teori Dasar AutoCAD dengan hasil belajar Gambar Konstruksi Bangunan.

\section{Daftar Pustaka}

Arikunto, S. 2002. Prosedur Penelitian Suatu Pendekatan Praktek. Jakarta: PT Rineka Cipta.

Bahrun. 2005. Bimbingan Belajar Yang Efektif Untuk Siswa SMP. Medan. 
Djamarah, B Syaiful. 2011. Psikologi Belajar. Jakarta : Rineka Cipta.

Depdiknas. 2003. Sistem Pendidikan Nasional. Jakarta: Gramedia.

Hamalik, O. 2002. Perencanaan Pengajaran Berdasarkan Pendekatan Sistem. Jakarta: Bumi Aksara.

Manullang, Rio. 2014. Desain Rumah Dengan AutoCAD dan Google Sketchup. Jakarta : PT. Elex Media Komputindo.

Matondang, Z. 2013. Statistika Pendidikan. Medan : Unimed Press

Muhibbinsyah. 2010. Psikologi Pendidikan. Bandung: Remaja Rosdakarya.

Noh, H Nurul. 2008. Hubungan antara keterampilan menggambar dan penguasaan teori dasar AutoCAD terhadap hasil belajar AutoCAD pada siswa kelas XI Program Keahlian Teknik Gambar Bangunan di SMK Negeri 1 Percut Sei Tuan. Skripsi. FT UNIMED.

Rosadi, Ahmad. 2008. Hubungan antara motivasi belajar dengan hasil belajar kewirausahaan pada siswa kelas II Program Keahlian Teknik Gambar Bangunan di SMK Negeri 5 Medan. Skripsi. FT UNIMED.

Sadirman. 2003. Interaksi dan Motivasi Belajar Mengajar. Jakarta : PT. Raja Grapindo Utama.

Siregar, D Sri. 2007. Hubungan efektivitas guru mengajar dan motivasi belajar terhadap hasil belajar statika bangunan pada siswa kelas I Program Keahlian Teknik Bangunan di SMK Negeri 1 Percut Sei Tuan. Skripsi. FT UNIMED.

Slameto. 2003. Belajar dan Faktor-Faktor Yang Mempengaruhinnya. Jakarta: Rineka Cipta.

Soma, H. 2002. Mahir Menggunakan AutoCAD Release 14. Jakarta:PT Elex Media Komputindo.

Sudjana, Nana. 2005. Metoda Statiska. Bandung: Tarsito.

Sugiyono. 2008. Metode Penelitian Pendidikan. Bandung: Alfabeta.

Winkel, W.S. 2005. Psikologi Pengajaran. Yogyakarta: Fakultas Psikolohi UGM.

Wiyono, H. Eko. 2007. Kamus Bahasa Indonesia Lengkap. Jakarta : Palanta 